\title{
Liam Ó Muirthile, An Fuíoll Feá - Rogha Dánta/ Wood Cuttings - New and Selected Poems
}

\section{Clíona Ní Ríordáin}

\section{(2) OpenEdition \\ 1 Journals}

\section{Electronic version}

URL: http://journals.openedition.org/etudesirlandaises/3851

DOI: 10.4000/etudesirlandaises.3851

ISSN: 2259-8863

\section{Publisher}

Presses universitaires de Caen

\section{Printed version}

Date of publication: 30 June 2014

Number of pages: $223-227$

ISBN: 978-2-7535-3449-0

ISSN: 0183-973X

\section{Electronic reference}

Clíona Ní Ríordáin, «Liam Ó Muirthile, An Fuíoll Feá - Rogha Dánta/Wood Cuttings - New and Selected Poems », Études irlandaises [Online], 39-1 | 2014, Online since 30 June 2016, connection on 22 September 2020. URL : http://journals.openedition.org/etudesirlandaises/3851 ; DOI : https:// doi.org/10.4000/etudesirlandaises.3851

\section{(c) (†)(}

Études irlandaises est mise à disposition selon les termes de la Licence Creative Commons Attribution - Pas d'Utilisation Commerciale - Partage dans les Mêmes Conditions 4.0 International. 


\title{
Comptes rendus de lecture
}

\author{
Book Reviews
}

Liam Ó Muirthile, An Fuioll Feá - Rogha Dánta/Wood Cuttings - New and Selected Poems, Baile Átha Cliath, Cois Life, 2013, 557 pages \& CD, ISBN 978-1-907 494-35-2, €20.
The Shaky Bridge
An droichead crochta
a bhainimis amach
chun é a chroitheadh
le spleodar óige amháin.
Samhail gan meirg gan mairg
idir bruacha dhá theanga
ag croitheadh i mbun dain:
Droichead Ui Riordáin.

The dedicatory poem of Liam Ó Muirthile's volume of New and Selected Poems refers to a legendry Cork bridge that crosses the River Lee, connecting Fitzgerald's Park to Sunday's Well. Located in a public amenity close to University College Cork, it is a suspension bridge constructed in 1927, one of four suspension bridges in Ireland. Known as "the Shaky Bridge" or "Daly's Bridge" and renamed by Ó Muirthile after the poet Seán Ó Ríordáin. Ó Muirthile also uses it as a metaphor for the connection between the two languages that he has moved between Irish and English: "Ireland, or that part of the island I call home, is a country of two languages historically, Irish and English. My life's work has been defined by the relationship between those two languages." (xxxix). The second verse of the poem implies that it is the tension between these two languages that has led to the creative impulse:

The suspension bridge we sought it out only to give it a right shake 
with the gusto of youth.

Symbol without rust without regret between the banks of two languages shaking with the frenzy of poetry Ó Ríordáin Bridge.

In the case of this volume, the translator who primarily helps Ó Muirthile to span the divide between the two languages and who shares his passion, his frenzy for poetry, is Gabriel Rosenstock. Ó Muirthile acknowledges his debt to his old comrade in his Author's Note as he outlines the task undertaken by his friend:

I would no longer have to provide literal translations, often glossed word for word. He would translate from Irish, and I could focus on my primary task without feeling that I was merely journeying deeper into the tangled undergrowth. This, in itself, released a huge surge of creative energy. (xl)

The phrase is revealing, indicative of the burden felt by Irish language poets since the move to producing bilingual editions of contemporary Irish language poetry occurred in the 1980s in the wake of Dermot Bolger's Raven Arts publication of An Tonn Gheal/The Bright Wave (1986). Ó Muirthile himself reveals that he was initially hostile to such an impulse, resisting translation as a solution to the problem of writing in a minority language $(\mathrm{xl})$. The present volume has enabled Ó Muirthile to write without worrying about the other language and, the danger of his poetry being smothered (to borrow Louis de Paor's image) by the sheer weight of the majority language, freeing him to plough into the opened ground of the unconscious. This, he reminds us in his author's preface, is the only translation he cares about: "[...] the only translation that really matters for a poet is translation in depth, in the unconscious." (xl)

The result is a volume of great scope and beauty, moving from Ó Muirthile's new poems back to the poems published in his initial collection Tine Chnámh (1984). It allows the reader to grasp the varied palette and multiple preoccupations of the poet, ranging from the engaged political poems like "Guilford Four", to one of awkward dialogue at Bealnablath with a Northern Nationalist: "Daoine boga sibhse theas, 'arsa cara,/'Muidne thuaidh cruaidh."'['You in the South are soft,' a friend says, /'We're of tougher mettle up north.'] (552/3). The poem is entitled "Thuaidh" (North) and the diction captures something of the bleb of the icicle that is to be found in Heaney's collection of the same name.

There are poems too of locale, ceol cheanntair the music of place as Seán Ó Ríordáin put it. Though Ó Muirthile long ago left "cocún Chorcaî" [the cocoon 
of Cork) (80/81), it remains visible in his poetry, in his dialect, in the long rollcall of his poet comrades whose names dot the pages of the book-Gerry Murphy, Louis de Paor, Greg Delanty, Michael Davitt, Colm Breathnach. His displacement to Dublin is an exile acknowledged in the poem "Deoraithe" [Exiles]. It describes an encounter between two Corkmen on an annual pilgrimage to Croke Park and celebrates the power of the hurling fields of Cork. Elsewhere the townlands, villages and poetic ancestors of Munster, Cork and Kerry in particular, are celebrated in the ode dedicated to poet Máire Bhuí Ní Laoighre (474-477) and the short sharp poems that resume the poetic art of Ó Rathaille, Ó Bruadair and Eoghan Rua Ó Súilleabháin. It is in these poems, with their sensual, fricative diction that the power of the attraction of writing in Irish is at its most tactile, its most convincing. In four short lines Ó Muirthile manages to distil the essence of each poet - rendering their work down into a potent brew that we can taste on the tongue:

\section{Ó Bruadair}

An gabha geal

ag greanadh friotail,

bocóidi focal á dteilgean

ina stiallacha líofa miotail.

Rosenstock provides an accomplished translation:

Silversmith

with polished friction

casting the studs

into flowing diction.

$(46 / 7)$

The translation, in this particular instance, acts as a commentary on the original "polished friction", and describes both Ó Muirthile’s poem and Ó Bruadair's oeuvre, perilously placed amidst the debris of the declining ancient Gaelic order.

As is fitting to one negotiating between two languages, one can also trace the influences of the major poets of those languages. Seán Ó Ríordáin is the voice with whom Ó Muirthile dialogues most frequently. In a prose poem, "Meáchan Rudaî" [The Weight of Things] (20-25) the central image of the weight of the son in his mother's womb "Mo mheáchan is tú dom iompar ar feadh naoi mhi" (20) sends us back to Ó Ríordáin's poem "Adhlacadh mo Mháthair": "Anois adhlacfad sa chroí a deineadh ionraic/Cuimhne na mná d'iompair me trí ráithe ina broinn." [And now I will bury in the heart made whole/The memory of the mother who carried me for nine months in her womb.] (Eireball Spideoige, 56). Seán Ó Tuama in Fili Faoi Scei- 
mble compared the impact this poem had on Irish language poetry to the influence of Baudelaire on nineteenth century French poetry. It is fitting that the very Francophile and Francophone Ó Muirthile should seek in Baudelaire's Poèmes en prose a response to the death of his own mother. The final line "Éadroime d'anama a luigh orainn ar nós braillín síoda i do leaba tar éis tú a adhlacadh". [The lightness of your soul that covered us like a silk sheet in your bed after we buried you.](24/5) reminds us of the electrifying opening verse of Ó Ríordáin's poem:

Grian an Mheithimh in uillghort,

Is siosarnach i sioda an tráthnóna,

Beach mhallaithe ag portaireacht

Mar screadstracadh ar an nóinbhrat.

June sun in an orchard,

And a rustling in the silk of evening,

A cursed bee humming

Is a screamtear in the eveningshroud

The silk sheet is thus also that of "Adhlacadh mo Mháthair", wrapping both poet-sons in the mourning shroud.

Ó Muirthile's dialogue is not restricted to a monolingual experience. These poems of filial piety and shriving mark an exchange too with the poetry of Seamus Heaney. It is the case especially in the poem "Torramh" [Wake](16-19). The image of the poet's family gathered at the mother's bedside, the emptiness left at the close of the poem, echo that of Heaney's "Clearances" sequence in The Haw Lantern (1987). An echo that is amplified by Rosenstock's translation where the final lines of the poem are rendered: "I went out/walking on air." (19), a plundering of Heaney's line "So walk on air against your better judgement" in "The Gravel Walk".

Ó Muirthile was aware of the playfulness of Rosenstock his translator, who can be compared to an Irish language Muldoon. It must be said that in this exercise Rosenstock has exercised a most unMuldoon-like restraint throughout the numerous translations he has made. Occasionally, as in this instance, there is the mischievous borrowing for the translation; sometimes Rosenstock chooses to cut a line in two and so ends up with a longer poem as in the case with "Faoin mBráca" [Under the Harrow] (38-42). Nowhere however does he cannibalise Ó Muirthile's work, as Muldoon has done with the poetry of Ní Dhomhnaill. These are accomplished translations that give access to the original. Rosenstock deserves the anglophone reader's thanks in making this exceptional body of work available. This accessibility is augmented by the presence of a CD that contains readings by both Ó Muirthile and Rosenstock. Cois Life is to be commended for making this handsome ensemble available for only $€ 20$. 
The title poem, "Fuíoll Feá" [Woodshavings] (114/5) is not perhaps the most captivating poem of the collection in poetic terms. However the poem is central to the poet's identity (he is after all a carpenter's son) and his enterprise. In the poem "Ailm" [Elm] (116/7) addressed to his fellow poet Tomás MacSiomóin the intertext is clearly "Cill Chais" the great poem of lament for the end of the Gaelic Age where the felled trees are symbolic also of the thinning out of the language. Images of replanting and trees abound in Ó Muirthile's work. He describes the poetic life in the following terms:

\author{
Throimaigh ár mbeo \\ thriomaigh ár ngui: \\ imionn ár n-arán \\ laethuil ina bhrus \\ smiota ar na liopaí. \\ [Our life has come to dust, \\ our prayers: \\ our daily bread \\ falls from our lips \\ in shattered crumbs.]
}

The paronomasia at play between "ár ndán" (our poem) in the following verse and "ár n-arán" (our bread) in this verse leaves us no illusions as to the loneliness and frustration of Ó Muirthile and his fellow Irish language poets (an explanation perhaps of the earlier paronomasia of the initial poem between "meirg" and "mairg", rust and regret); they are frequently castigated in the Irish media as both irrelevant and inferior. This wonderful book proves those naysayers wrong on both counts.

Clíona Ní RíORDÁin

Université Sorbonne Nouvelle-Paris 3

Derek Mahon, La Mer hivernale et autres poèmes, traduit de l'anglais (Irlande) et préfacé par Jacques Chuto, Édition bilingue, Le Chambon-sur-Lignon, Cheyne éditeur, coll. « D’une voix l'autre », 2013, 172 p., ISBN 978-2-84116193-5, $24 €$.

Ce recueil rassemble des textes choisis dans les Collected Poems de 1999, mais les révisions opérées pour les New Collected Poems de 2011 ont été prises en compte par 
le traducteur : quarante-huit poèmes choisis de manière à refléter les préoccupations majeures d'un homme qui " n'aime guère son époque " et s'en prend aux travers du monde contemporain. Il dénonce la défiguration de l'Irlande, depuis le massacre du milieu naturel (déforestation de l'Ulster au XviI ${ }^{\mathrm{e}}$ siècle dans " Going Home »), jusqu'à l'invasion tonitruante des cars de touristes " grotesques en casquette de baseball et survêt en nylon » ("Night Thoughts ", extrait d'une suite justement nommée «Decadence »). Le poids du passé, Pompéi, Treblinka, des « Troubles » ou encore de la guerre civile ne peut être évacué, et c'est la tâche du poète que de parler au nom de tous "les suppliants sans voix " ("A Disused Shed in Co. Wexford"). Il fustige un mode de vie où le heavy metal le rend "fou de rage " tandis qu'il s'accroche à ses livres, " ces trucs périmés » ("Rock Music »), ou à la beauté de la nature. L'uniformité sans âme a tout envahi. Avec «les Dieux bannis " Mahon rêve d'un monde « sans ordinateurs ni voitures/Ni cieux nucléaires,/Où la pensée, c'est caresser des pierres,/Et la sagesse, un moment de silence quand se lève la lune. » On le voit se raidir pour dépasser l'amertume, la nostalgie et le désespoir (l'émouvant "Dawn at St Patrick's »), et s'en remettre aux « Consolations de la philosophie " pour " vivre la vie que nous aurions pu vivre " sans exclure qu'un jour l'humanité prenne un nouveau départ. Jacques Chuto sait ce que traduire veut dire : il a déjà traduit Mahon (traducteur lui-même) en 1991, et fréquenté longuement un certain J.-C. Mangan expert en la matière... Décidé à s’en tenir « à la fidélité sans renoncer à la beauté ", entouré des nombreux conseils de l'auteur auquel il rend hommage, il s'y entend à maintenir une forme strophique virtuose ("The Hunt by Night "), à trouver des rimes en écho à l'original sans forcer le sens (" Derry Morning »), et surtout à imprimer à ses traductions le rythme qui serre au plus près celui de la voix du poète : "La Mer hivernale ", credo poétique de Mahon, heureusement choisi pour donner son titre au recueil, est à cet égard une belle réussite où la " litanie des toponymes " chère à John Montague, en mêlant l'Irlande et la Grèce, invite à « Repartir à zéro, de l'ancien faire/Un renouveau. » Ce recueil est bilingue : en comparant l'original et la version française, le lecteur pourra saisir par quels procédés délicats est rendue la complexité de l'œuvre. Mahon rend hommage aux écrivains chers à son cœur, cités nommément ou perçus en filigrane dans la trame des textes : Ovide, Pindare, Swift, J.G. Farrell, McNeice, Heaney, Baudelaire, Camus, et beaucoup d'autres. Les notes suffisantes et précises éclairent les points obscurs. Ce livre élégant est un bel objet qui ajoute au plaisir de la double lecture. Qu'on ne se méprenne pas : la critique véhémente de Mahon à l'égard du monde qui l'entoure est avant tout celle d'un poète de première grandeur. Ici, il a trouvé son traducteur.

Claude Fierobe Université de Reims Champagne-Ardenne 